\title{
KERK AS INSTITUUT ... EN INSTITUSIONALISERING?
}

\section{Die kerkbegrip verskraal tot 'n instituut}

Op teologiese gebied waarsku al meer stemme teen die onderskeiding tussen kerk as instituut en kerk as organisme en pleit dat die begrip kerk weer gelaai word met die Bybelse inhoud van kerk-wees omdat daar 'n Christen-wees deur die geloof is. 'n Mens hoor egter ook onder ons al meer hoe die term ,kerk" met 'n verskraalde instituut-betekenis gebruik word. Dit is om van te skrik wanneer jy hoor van die "die kerk se taak" teenoor die jeug, die lidmate, die moderne mens en wie ook al... Is die jeug en die lidmate nie kerk nie? Staan die kerk as instituut of as burokrasie klaar los van die lidmate?

Vanselfsprekend sien die sosioloog vanuit sy dissipline ,die kerk" raak wat "teenoor sy lidmate" 'n taak het of 'n taak pretendeer... Hy kyk met alles behalwe die teologiese begrippe en gerusstellinge op hierdie gemeenskap in die samelewing. Uiteraard sê hy wat hy sien en nie wat die Bybel hom leer nie. Juis daarom bring so 'n beskouing op sy eie wyse prikkelende selfontdekking met hom mee. Dit het 'n mens ervaar toe dr. C. J. Alant, sosioloog van Unisa, voor die Pretoriase G.T.V. gepraat het oor „Enkele aspekte van die Stadsbediening".

\section{Kommunikasieprobleme in die struktuur van die kerk}

Hy het begin met die kommunikasieprobleme tussen die formele en informele strukture van 'n samelewingsverband. Ook t.o.v. "die kerk" is daar ongetwyfeld probleme om die "kerk as organisme" en die ,kerk as instituut" en hulle verhouding sinvol te begryp (mag ons ooit van 'n ,hulle" praat of is dit slegs kante van dieselfde saak?). Kommunikeer die formele en informele strukture in "die kerk" na behore? Om Sondag te begin: Begryp die "gemeente" ooit waarom dit gaan in die afkondigings, die vorme van die liturgie, die kerkorganisasie? Het hulle daar deel aan? Het die „kerk” as ,gemeente” of selfs as ,kerkraad" veel belang by wat aangaan op klassisse en sinodes - of by die "deputategroepe"?

Dr. Alant gaan uit van die standpunt dat die „ou landelike Afrikanerdom" in die proses van verstedeliking onherroeplik verbygegaan het. Ook t.o.v. die kerk ontstaan behoefte aan nuwe verbindinge. Behoeftes word soms wel raakgesien, maar die kerklike oplossings bly triviaal, allerlei skemas en eksperimente t.o.v. liturgie ens., wat die probleem eintlik net aksentueer en vererger.

\section{Die proses van institusionalisering en burokratisering}

As sosioloog tipeer dr. Alant die basiese probleem van die kerk in ons eeu dié van institusionalisering en burokratisering.

'n Bepaalde verskynsel soos die kerk tree na vore en verwerf sy staanplek in die menslike samelewing omdat hy 'n behoefte vervul en 'n bepaalde diens lewer.

Gaandeweg begin hy almeer institusionaliseer om die plek te 
bly vervul. Die eienaardige verskynsel doen hom dan voor dat hoe meer daar geïnstitusionaliseer word om tot beter of groter georganiseerde taakvervulling te kom, hoe meer ontwyk die beoogde utopia hom. Kortom, hoe meer jy bou aan die institusionele, hoe meer verloor die instituut kontak met die gewone leef-werklikheid. Die mens vra immers diens van die kerk, nie die instituut self om homself nie.

Institusionalisering rig hom op die eie belang van die struktuur wat georganiseer word. T.o.v. die kerk beteken dit dat die „kerk” as instituut ' $n$ doel in homself word. Die instituut kom self sentraal te staan in al sy aktiwiteite. Dit gaan om sy organisasie, sy lidmate, sy eredienste, sy stem hier of daar, sy deelname of verteenwoordiging, sy opinie, oordeel of uitspraak hieroor of daaroor, ens.

Hierdie institusionalisering bring die begeleidende verskynsel van burokratisering na vore. Die eie belange van die instituut word gepolariseer in geïnstitusionaliseerde figure, persone, funksionarisse, aktiwiteite, ens. Om as sodanig te bly voortbestaan en sy burokrasie te dra, het die ,kerk" bydraes nodig; moet hy met of sonder lapwerk en inspuitings, probeer om te oorleef, in elk geval met behoud van sy institusionele patroon.

\section{Faktore van buite help institusionaliseer}

In die proses van institusionalisering het idiome van buite af, byvoorbeeld die begrip „kommissie”, gehelp om die kerk te struktureer. Die strukture waarin die kerk in en deur „kommissies" werk terwyl die informele struktuur daarbuite bly, word deel van die institutêre vorm. Om eie probleme te ontwyk, kan die „kerk” na buite kritiseer.

\section{Die mens benader die kerk met 'n konsumpsie-vraag}

Die mens kom egter hierdie instituut teë met die konsumpsie-motief, naamlik „Wat kry ek van die kerk?" (Vergelyk hier ook E. A. Nida, New Religions for Old, onder die Boekbesprekings, t.o.v. Lux Mundi 3 ). Veelal kry die mens eintlik die antwoord: „Jy moet kom om die kerk aan die gang te hou". "Wees lidmaat met die oog op die kerk self!"

\section{Mislukte lapwerk}

Alant meen die stad is vol tragiese voorbeelde van goedbedoelde pogings om substrukture in die kerk te hervorm; om die privatisering van die kerk en sy burokrasie te deurbreek d.m.v. gemeente-etes, voetbalwedstryde, ens., maar die pogings word self alweer verydel deur die haas wat organisasie meebring. Die „leke” bly weerstand bied en hou vol: „Ons het mos 'n dominee vir die job".

Ondertussen verkrummel die ou landelike huisstruktuur. Die man is meer tuis by sy maats en in die klub as in sy huis. - Ons gemeente-patroon laat nie klein gedesentraliseerde eenhede toe nie.

Die pogings om ad hoc aksies op jeuggroepe of vakgroepe toe te spits, val plat, omdat hulle nog te tradisioneel institusioneel gerig is. Hulle bly geskoei op patroon van die instituut met sy burokrasie. 
Ondertussen openbaar die „Jesus-people" dat die behoefte aan ge. meenskap basies sentraal by die moderne mens lê.

\section{Die instituut mis die behoeftes}

Alant meen die „kerk” en ,sinodes” kom die behoeftes te veel met die dogma en kitsklaar oplossing uit boeke tegemoet, in plaas van om op empatiese vlak te vra: Wat is aan die gang?

Die verwyt kan gemaak word: Julle dominees wil die probleem oplos sonder om die probleem te besef. Volgens Hogarth kom die „change" of hervorming wat die jeug verlang neer op 'n hunkering na ,phantasy and festival spirit in the church".

Volgens Alant moet die ,kerk" die norm bring, maar die vorm vrylaat - ook t.o.v. aanbidding.

\section{Het institusionalisering van die kerk nie ons probleem geword nie?}

'n Mens sou vanselfsprekend vanuit teologiese dissipline met Alant kon redeneer. Jy kon vra of vorm en norm t.o.v. kerk geskei kan word, ens? Maar die ideaal en die praktyk laat 'n mens tog vra: Was dit nie 'n kenmerk van gereformeerde Sinodebesluite tot diep in hierdie eeu dat hulle reglementering wars was en die middelmatige dinge nie wou institusionaliseer nie? Hoor mens nie vandag (en dikwels so ten onregte) "die Sinode het so of so besluit" daarom "moet" dit nou sus en so nie?

Het die weelde van meer dominees nie in baie opsigte die selfwerksaamheid van ouderlinge en lidmate vervang nie? Kortom, het 'n heillose institusionalisering met 'n gepaardgaande burokratisering in deputate, spesialiste, teoloë, professore en dominees nie na vore getree nie, terwyl die kerk as vergadering van Christene verkluim nie?

Voltrek die ,institusionalisering" hom nie juis daar waar die stem van die ,lastige" ouderling of lidmaat in die kerkraad stil gemaak word nie - of waar die prinsipiële dialoog op die klassis of sinode ontloop word nie, veral as 'n kommissie nog nie ,gestudeer" het nie, of as 'n ,,presedent" of 'n ,,besluit" die konfrontasie met 'n lastige probleem kan fortifiseer.

Het institusionalisering en burokratisering ook ons probleem geword? Is die sg. „,kerk as instituut" nie maar eintlik dié enigste „kerk" in ons begripswêreld nie?

\section{Verskoning vir laat verskyning van vorige uitgawe}

Die redaksie bied sy verskoning aan dat die vorige uitgawe so laat verskyn het en gevolglik ook hierdie nommer vertraag het. Die drukkers was oorlaai met werk. 
Finansiële verslae

Kas van G.T.V. Hoofbestuur op 31-3-73

Lopende rekening Volkskas

R $\quad 0,79$

Spaarrekening Volkskas

103,14

Rente verdien do.

In die Skriflig 1-4-72-31-3-73

\section{Inkomste:}

Balans per kasboek 31-3-72

R583,55

Donasies

246,55

Intekengeld

205,43

\section{Uitgawes:}

Drukwerk, versending

R1 476,91

Administrasie

Bankkoste, rente

Balansstaat:

Oortrokke rekening Volkskas

R 457,12

Saldo Spaarrekening

1200,00

Rente verdien do.

\section{Dankbetuiging}

Die redaksie wil graag ds. P. W. Bingle, tot onlangs van Pretoria-Wes, baie hartlik bedank vir sy troue en gewaardeerde dienste as sekretaris van die redaksie. Weens sy verhuising na Kaapstad het dit vir hom nodig geword om sy bedanking aan die Hoofbestuur voor te lê. Die redaksie wil graag vermeld dat ds. Bingle nog voor sy vertrek eers die rekenings vir 1973 uitgestuur het. Hy het die belange van In die Skriflig op sy hart gedra en met onderskeiding gedien.

\section{Jaarvergadering 5 Junie 1973}

Die redaksie hoop dat hy in 'n volgende uitgawe die voordragte kan publiseer wat op die Jaarvergadering te Pretoria gelewer is. As hoofbestuur vir die volgende termyn het die vergadering aangewys: Prof. B. Spoelstra (voorsitter); dr. K. S. van Wyk de Vries (ondervoorsitter); ds. C. J. H. Venter (sekretaris-penningmeester); dr. C. J. Malan; prof. L. F. Schulze.

Die vergadering het aan die Hoofbestuur opgedra om 'n ondersoek in feite na die prediking op teologies-wetenskaplike wyse te beplan en met behulp van die takke aan te durf. Die resultate van so 'n ondersoek kan dan as tema vir bespreking dien op 'n volgende jaarvergadering. 